\title{
Effects of reduced salinity and seston availability on growth of the New Zealand little-neck clam Austrovenus stutchburyi
}

\author{
Islay D. Marsden* \\ Zoology Department, University of Canterbury, Private Bag 4800, Christchurch, New Zealand
}

\begin{abstract}
Estuarine bivalves are exposed to spatial and temporal variations in salinity and seston quality and quantity. This is the first study to investigate the effects of salinity reduction and phytoplankton availability on the survival, health and growth of a burrowing bivalve. The intertidal clam Austrovenus stutchburyi survived $6 \mathrm{wk}$ of laboratory storage in dilute seawater $(20 \%)$ at $15^{\circ} \mathrm{C}$. In

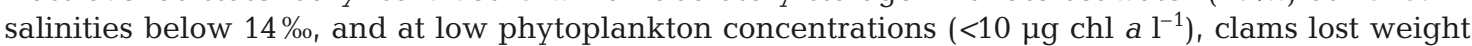
and mortality occurred within 4 wk of exposure. With high phytoplankton availability $(>20 \mu \mathrm{g}$ chl a $\mathrm{l}^{-1}$ ), some clams survived $6 \mathrm{wk}$ exposure to $7 \%$. Salinity and quality of seston over 5 shellfish beds varied both amongst and within sites. Chl a concentration at high tide was variable between sites, but was generally below $8 \mu \mathrm{g} \mathrm{l}^{-1}$. Seston total particulate matter (TPM) ranged from 25 to $400 \mathrm{mg} \mathrm{l}^{-1}$, and particulate organic matter (POM) from 3 to $31 \mathrm{mg} \mathrm{l}^{-1}$. Clams transplanted to other sites in the estuary quickly adapted to new environmental conditions. Average growth rates of clams caged at 4 estuary sites for 6 mo (October 1997 to April 1998) were low, between 0.17 and $0.35 \mathrm{~mm} \mathrm{mo}^{-1}$. Total length increment correlated positively with low-tide temperature, salinity and average chl a concentration. After $2 \mathrm{mo}$, there was a direct linear relationship between transplanted clam standard condition index $\left(\mathrm{CI}_{\text {shell }}\right)$ and length increment. The integrated laboratory and field studies confirm that salinity dilution, together with low phytoplankton availability, reduces growth and condition of this shallowburrowing estuarine clam.
\end{abstract}

KEY WORDS: Chl a C Clam condition · Salinity effects · Growth · Seston · Quality · Quantity · Temperature

Resale or republication not permitted without written consent of the publisher

\section{INTRODUCTION}

Estuarine benthic suspension-feeding bivalves are exposed to spatial and temporal variations in the environment that can affect all aspects of their behaviour, physiology, energetics, population biology and growth (Shumway \& Newell 1984, Navarro 1988). Bivalve feeding mechanisms and energetics have been extensively studied, but the relationship between these physiological processes and environmental factors that affect growth is not always clear, especially for burrowing species (Bricelj \& Malouf 1984, Thompson \& Nichols 1988, Grant 1996, Iglesias et al. 1996, Hawkins et al. 1998).

Many estuarine clams have both a critical and an optimal salinity for growth, and some species show geographical differences in their salinity tolerances (Newell 1991). Salinity has been widely implicated as affecting the energy budget and growth of estuarine bivalves (Shumway 1982, Kautsky 1982); however, few studies have examined this critically. In mussels, small reductions in salinity (ca. 10\%) can reduce growth (Gruffydd et al. 1984), and fluctuating salinities can result in mortality due to depletion of biochemical reserves in the mussels Mytilus edulis and M. trossulus (Gardner \& Thompson 2001). In a recent study, Shriver et al. (2002) studied the effects of salinity and food availability on the growth of suspended juvenile bay scallops. This scallop is usually found in high salinity estuaries, and was previously thought to have little tolerance for low or reduced salinities. Mortality increased both with reduced salinity 
and high densities of competitors. Growth rates were high, but interestingly, growth did not increase with higher phytoplankton concentration. This scallop research contrasts with previous research on bivalves, including cockles, clams and mussels, where food availability is thought to be the major factor affecting bivalve growth (Grizzle \& Morin 1989, Iglesias et al. 1992, Hawkins et al. 1998). These studies suggest a potentially complex relationship between salinity and other environmental variables (including food availability, quantity and quality) and the growth of estuarine bivalves.

The endemic little-neck clam Austrovenus stutchburyi, locally known as the cockle or tuangi, is a shallow-burrowing species found at mid- to low-tide in estuaries and protected sand flats throughout New Zealand. Its ecology and distribution have been described by Larcombe (1971), Stephenson (1981) and Blackwell (1984). Transplant studies by Dobbinson et al. (1989) found that tidal height was the major factor affecting clam growth-rate. Compared with mid- and high-tide clams, the longer immersion period for lowtide bivalves, together with higher food availability, was thought to explain the high bivalve growth rates in clam populations exposed to normal salinity conditions ( $32 \%$ and above). Little-neck clams, however, occur in habitats where they are exposed to reductions in salinity down to $14 \%$ (Marsden \& Pilkington 1995). In estuaries, the quality and quantity of seston will vary on different temporal scales, over tidal, lunar and seasonal cycles, and there will also be nutrient input from rivers and treated waste water.

The most common approach to investigating the effects of combined environmental factors on the growth of bivalves is to study field populations or experimental transplants. Researchers have selected a range of sites, but rarely have the salinity effects been considered, even in well-studied species including Macoma balthica and Mercenaria mercenaria (Grizzle \& Morin 1989, Harvey \& Vincent 1990, 1991). Complementary laboratory studies are useful in identifying the specific effects of particular variables, and these have greatly contributed to our understanding of the energetics and effects of food quality on the European cockle Cerastoderma edule (Iglesias et al. 1992, Urrutia et al. 1996, Navarro \& Widdows 1997). However, these studies did not include salinity as a part of the response model.

The little-neck clam is commercially harvested in New Zealand and is of high cultural value, with many people collecting clams for themselves. This species has disappeared from certain areas, and a number of unpublished field trials have assessed whether shellfish beds can be re-established using transplants. The success of these programmes will depend upon whether transplants are likely to cope with environ- mental conditions, including reduced salinity. The present study was designed to evaluate the effects of reduced salinity on clams through a combination of short-term laboratory studies, long- and short-term field transplants, and the monitoring of field populations. Clam health was assessed using a standard condition index $\left(\mathrm{CI}_{\text {shell }}\right)$, and the relationship between this index and growth was quantified.

\section{MATERIALS AND METHODS}

Laboratory experiments. Experimental clams were collected from Beachville (see 'field sites and collecting methods' for fuller description), where they are exposed to a seasonal and daily salinity range between 28 and 34\%o (Marsden \& Pilkington 1995). Two $6 \mathrm{wk}$ laboratory experiments investigated the combined effects of salinity and phytoplankton availability on the condition index of Austrovenus stutchburyi at $15^{\circ} \mathrm{C}$ with a $12 \mathrm{~h}$ dark:light regime. An independent tidal tank was used for each experimental condition. The tidal tanks consisted of $2 \times 45 \mathrm{l}$ plastic tanks placed above each other with a pump to recirculate the seawater. The bottom tank was aerated to ensure oxygen concentrations remained high and there was no build up of ammonia. The seawater was collected from Lyttleton Harbour and filtered through Whatman GF/C glass filters. Experimental salinites were made up by dilution using distilled water (Gruffydd et al. 1984). The salinity in each tidal tank was checked and adjusted every $4 \mathrm{~d}$, and the water was completely replaced every $2 \mathrm{wk}$. The tidal cycle was maintained to be the same as in the field using a delay timer, and included a $3 \mathrm{~h}$ low-tide period when the pump was stopped, and seawater was allowed to drain from the experimental vessels in the upper tank into the lower tank.

Expt 1 began on October 22, 1997 using 4 tidal tanks and 12 similar groups of 15 clams, 9 to $29 \mathrm{~mm}$ shell length (mean $\pm \mathrm{SD}, 20.1 \pm 4.3 \mathrm{~mm}$ ). Twenty clams collected at the start of the experiment provided initial values for the weight relationships and condition index $\left(\mathrm{CI}_{\text {shell }}=[\right.$ dry tissue weight $/$ shell dry weight $\left.] \times 100\right)$ (Crosby \& Gale 1990). This index is thought to be a reliable stress indicator for bivalves and, in this and other species, is generally independent of shell length (Rainer \& Mann 1992, Marsden \& Pilkington 1995).

The experimental vessels were 21 uncovered plastic ice-cream containers $(15 \times 15 \times 8 \mathrm{~cm}$ depth), which were perforated to allow the seawater to drain out at low-tide. They contained $5 \mathrm{~cm}$ of well-mixed fine sand that had been collected from the estuary mouth and air dried. The vessels for each treatment were completely submerged in the top tank and the clams were intro- 


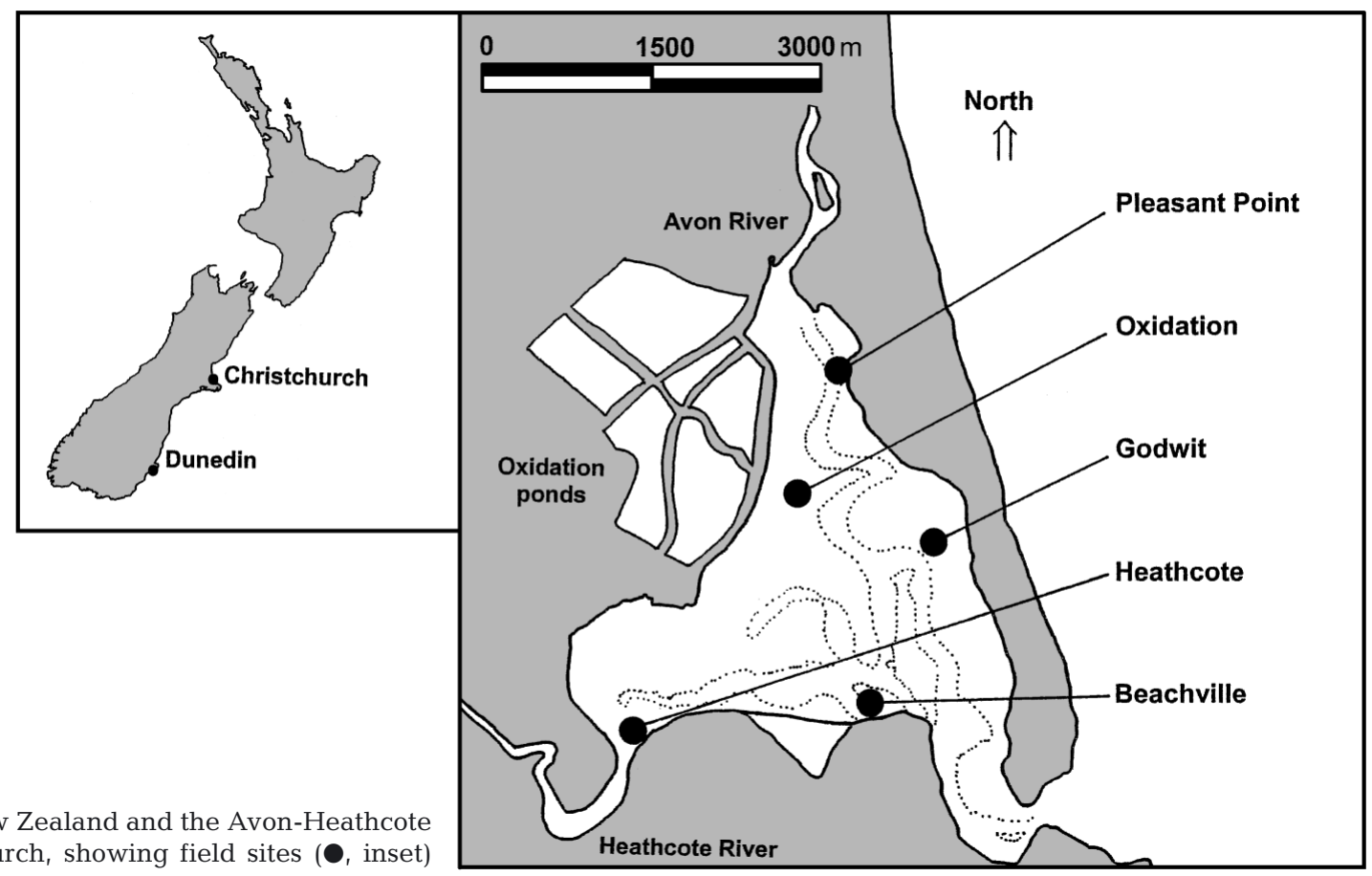

Fig. 1. Map of New Zealand and the Avon-Heathcote Estuary, Christchurch, showing field sites , inset)

duced after $6 \mathrm{~h}$ of equilibration. There were 2 salinity treatments, 34 and $20 \%$, and high or low phytoplankton conditions provided by the addition of a daily ration of Isochrysis galbana close to the evening hightide. Phytoplankton were harvested during the logarithmic growth phase at a standard concentration, verified at intervals by cell counts and fluorimetry readings. Each day, $100 \mathrm{ml}$ of concentrated culture (ca. $294 \mu \mathrm{g} \mathrm{chl} \mathrm{a}^{-1}$ ) was added to the high phytoplankton treatments, and $10 \mathrm{ml}$ to the low phytoplankton treatments. These provided bursts of seston concentrations in the tidal tank, on average between 5 and $10 \mu \mathrm{g} \mathrm{chl} \mathrm{a}$ $\mathrm{l}^{-1}$ in the low seston treatment (values similar to concentrations from local oceanic seawater) and 20 to $50 \mu \mathrm{g} \mathrm{chl} \mathrm{al}^{-1}$ in the high seston treatment (values similar to low-tide estuary sediment concentrations). Irregular measurements were made on phytoplankton concentrations using fluorimetry. After 2, 4 and $6 \mathrm{wk}$, 1 experimental container was randomly removed and the clams were separated from the sediment. The shell length was measured to the nearest $0.01 \mathrm{~mm}$ using vernier callipers, the tissue was dissected from the shell, and both the shell and the tissue dried at $60^{\circ} \mathrm{C}$ for $48 \mathrm{~h}$.

Expt 2 followed on directly after Expt 1 on December 19, 1997 using the same equipment. However, there were 5 treatments: $34 \%$ with high phytoplankton availability (a time compari- son for Expt 1) and 2 salinities, 14 and $7 \%$, with high and low phytoplankton as described earlier. Clams used in Expt 2 were of a similar length and $\mathrm{CI}_{\text {shell }}$ to those used in Expt 1.

Field sites and collecting methods. Clam populations were sampled from 5 mid- to low-tide shellfish beds close to river channels within the AvonHeathcote Estuary, Christchurch, South Island, New Zealand $\left(43^{\circ} 31^{\prime} \mathrm{S}, 172^{\circ} 44^{\prime} \mathrm{E}\right)$ during spring and summer (October 1997 to April 1998). This shallow estuary has an average depth of approximately $1.4 \mathrm{~m}$, and the sites were chosen along an environmental gradient of salinity, seston availability and sediment characteristics (Fig. 1, Table 1). The sediments from the 2 sites closest to the estuary mouth had a higher proportion of sand than those (2) that were close to the rivers. Oxidation was intermediate, and the sediments contained relatively high concentrations of trace metals. Clam populations within the estuary vary from less than

Table 1. Sediment characteristics and trace metal concentrations of, copper, zinc and lead $\left(\mu \mathrm{g} \mathrm{g}^{-1}\right.$ ) from areas close to present study sites, recorded in December 1997, as part of another research study

\begin{tabular}{|lcccrrr|}
\hline Site & \% sand & \% silt & \% clay & $\mathrm{Cu}$ & $\mathrm{Zn}$ & $\mathrm{Pb}$ \\
\hline Godwit & $97-99$ & $1.4-2.5$ & $0.2-0.7$ & 2 & 28 & 4 \\
Oxidation & $72-78$ & $20.2-25.8$ & $2.3-2.8$ & 11 & 74 & 14 \\
Pleasant Pt & $27-47$ & $49.8-67.6$ & $3.1-6.0$ & 15 & 100 & 20 \\
Heathcote & $47-60$ & $38.5-56.3$ & $1.3-2.2$ & 7 & 79 & 17 \\
\hline
\end{tabular}


$50 \mathrm{~m}^{-2}$ to more than $1000 \mathrm{~m}^{-2}$ (Stephenson 1981). Study sites were selected where densities were close to or below 200 ind. $\mathrm{m}^{-2}$ (Marsden \& Pilkington 1995), and the emersion time was up to $4 \mathrm{~h}$ at low tide. Clams from each site were collected by hand after digging $20 \times$ $20 \mathrm{~cm}$ quadrats and sieving through a $2 \mathrm{~mm}$-mesh garden sieve. Twenty individuals were used to assess the initial weight relationships and $\mathrm{CI}_{\text {shell }}$.

For the laboratory and field-transfer experiments, clams were collected from Beachville, which was the site closest to the estuary mouth. The small clams were collected from a small area adjacent to the main shellfish bed close to a rocky part of the estuary channel, where drift algae collect.

Population samples and transplant experiments. The weight relationships and $\mathrm{CI}_{\text {shell }}$ of 20 individuals from the 5 clam populations in the field were followed over the duration of Expt 1 (October to December), with samples taken at $2 \mathrm{wk}$ intervals, $1 \mathrm{~d}$ after measurements were made on clams in the laboratory experiment. Also, to assess the effects of changing environmental conditions on a single population, clams from Beachville were caged at each of the 5 field sites (Fig. 1). The experimental procedures were tested by transplanting clams from Beachville (high salinity site) to Heathcote (low salinity site) and comparing the survival of the transplants with those of self-transplanted clams from Heathcote. Over a period of 3 wk there was no mortality within the cages. The cages were constructed from the same 21 plastic ice-cream containers used in the laboratory experiments. The sides and bottom were perforated and the lid was made from $1 \mathrm{~mm}$ mesh, which allowed the seawater to enter but excluded bird and fish predators. The numbered cages contained $5 \mathrm{~cm}$ of the same sand used in the laboratory experiment. At each site, 4 cages containing 20 premeasured clams (10 to $30 \mathrm{~mm}$ shell length) were set-up close to the edge of the channel. They were tied together and labelled with a stake so they could easily be relocated. One cage was removed at each 2 wk interval when the natural clam populations were sampled.

Field measurements. At each low-tide collection, $200 \mathrm{ml}$ water samples were taken from the channel, and ca. 2 to $3 \mathrm{~mm}$ of sediment from the exposed intertidal mudflat surface was removed for temperature, salinity (refractometry) and chl a (fluorimetry, calibrated using a chl a standard) measurements. In late November, the seston availability at high tide was assessed from samples from both the surface water and just above the sediment-water interface over the clam beds at each site. Four $200 \mathrm{ml}$ samples were collected to estimate chl a by fluorimetry together with a 11 seston sample. The sample was filtered through preweighed and ashed glass filters to estimate total seston (total particulate matter; TPM), and then ashed at $400^{\circ} \mathrm{C}$ for $4 \mathrm{~h}$ for estimates of organic and other volatile solids (total volatile solids; TVS). Two independent samples from each water mass were collected for salinity measurements and an average temperature recorded during sampling. In early December, similar measurements were made at the sediment-water interface over the shellfish beds by collecting a $1 \mathrm{l}$ water sample each hour over a $6 \mathrm{~h}$ period from $3 \mathrm{~h}$ before high tide to $3 \mathrm{~h}$ after high tide.

Growth experiment. The 6 mo experiment was set up in early October at all 5 sites using 6 numbered cages (as in the transplant experiment described earlier) containing 15 pre-measured individuals collected from Beachville. Although the original experimental design included a transplant back to Beachville, this was unsuccessful because of human interference and instability of the cages within the established shellfish bed. Cages were checked weekly and any accumulated sea lettuce (Ulva lactuca) was removed. Each cage was placed randomly, at least $50 \mathrm{~cm}$ apart, at the low-tide level. One of the cages was recovered from each of the remaining 4 sites bimonthly up to April 1998. The cages were returned to the laboratory where the clams were measured. New growth could easily be seen on the shell margin, acting as a natural marker (Dobbinson et al. 1989). The starting length was checked to identify the individuals, and the length increment calculated for all living individuals. Measurements were not made on dead individuals that were retained within the cage. The clams were measured and weighed as described previously. Fieldclam populations were sampled on the days that the transplant clams were collected; weight relationships and $\mathrm{CI}_{\text {shell }}$ were calculated for 20 individuals from each site at the start of the growth experiment, and then for 10 clams at the remaining time intervals.

Statistical analyses. For Austrovenus stutchburyi, as for other bivalves, there was a significant effect of body size, represented by shell length $(x)$, on the total dry tissue weight $(y)$, following the power function $y=a x^{b}$, where $a$ is the intercept and $b$ the slope of the line (Harvey \& Vincent 1990, 1991, Grant \& Thorpe 1991). Data were therefore logarithmically transformed to produce linear relationships so that the best-fit regression lines could be compared by analysis of covariance (ANCOVA). This analysis tests for significant differences in the transformed dry weight (regression-line elevations) allowing for differences in the transformed shell length, provided that there are no significant differences between the regression coefficients (slopes) of the lines. All data from the laboratory experiments, the natural field populations and the field transplants were examined for weight differences using correlation and regression analysis. In all cases, there was a significant effect $(p<0.05)$ of shell length on the tissue 
dry weight. Where significant differences were found, Tukey's multiple comparison post-hoc test was used to group regression relationships that were similar.

The dry weight condition index, $\mathrm{CI}_{\text {shell, }}$ for Austrovenus stutchburyi was independent of shell length and values were compared using 1- or 2-way ANOVA. Prior to analyses, homogeneity and normality of data were tested as described in Zar (1999). To compare temporal changes in clam $\mathrm{CI}_{\text {shell }}$ within and amongst sites, repeated-measures ANOVA was used and the means compared by multiple comparisons using Tukey's method. In the growth experiment, the independent length increments were compared using 1-way ANOVA following logarithmic transformation. The ANOVA results were considered to be significant if $\mathrm{p}<0.05$.

Environmental and seston data contained few replicates, and comparisons between sites and/or over time were made using 1- or 2-way ANOVA, using arcsine transformations for \%TVS data. All analyses were done using Statistica version 6.0.

\section{RESULTS}

\section{Laboratory experiments}

In Expt 1, all clams collected from Beachville survived $6 \mathrm{wk}$ laboratory exposure to salinities of 34 and $20 \%$. The mean dry tissue weight in the 4 salinity/food combinations ranged between 0.06 and $0.1 \mathrm{~g}$. There was a significant effect of experimental regime on the weight relationships (Fig. 2A) $\left(\right.$ ANCOVA $F_{\text {all effects }}=$ 2.95; $\mathrm{p}<0.001)$. There was no loss in the adjustedmean tissue dry weight throughout the 6 wk period, regardless of food availability. There was a slight increase in tissue weight at $34 \%$ with high phytoplankton availability after $4 \mathrm{wk}$ and also in the $34 \%$ low phytoplankton treatment after $6 \mathrm{wk}$ (Tukey's posthoc test). There were significant differences in mean $\mathrm{CI}_{\text {shell }}$ (ANOVA $F=3.65$ ). However, following $2 \mathrm{wk}$ of laboratory storage, the value was similar for all treatments (Fig. 2B) (ANOVA $F=1.61 ; \mathrm{p}=0.10$ ), remaining within narrow limits from 4.2 to 5.1 regardless of the salinity and food regime. Thus, on exposure to 20 and $34 \%$, increased phytoplankton availability did not result in consistent increases in either the body dry tissue weight or $\mathrm{CI}_{\text {shell }}$.

In Expt 2,- where clams were exposed to 34, 14 and $7 \%$-although the mean $\mathrm{CI}_{\text {shell }}$ was lower (4.8) than at the start of Expt 1 (5.2), the $\mathrm{CI}_{\text {shell }}$ valves were similar for all 3 salinities (repeated-measures ANOVA). Exposure time, phytoplankton concentration and salinity affected clam survival. Clams did not survive $4 \mathrm{wk}$ exposure to $14 \%$, or $6 \mathrm{wk}$ exposure to $7 \%$ salinity and low phytoplankton. There was $50 \%$ mortality at $7 \%$ with high phytoplankton following 6 wk exposure. All individuals survived in the remaining treatments, and there was similar variation in their mean tissue dry weights. There was a significant effect of treatment on the adjusted-mean dry weight (Fig. 3A) (ANCOVA $F_{\text {all effects }}=5.72 ; \mathrm{p}<0.001$ ), with significant weight gain following 2 wk exposure to $7 \%$ with high phytoplankton. Clams were able to maintain their body weight for up to $4 \mathrm{wk}$ when exposed to salinities down to $7 \%$ in the presence of high phytoplankton. There was significant weight loss after 6 wk exposure in all treatments, except for control clams, which maintained their initial body weight. The $\mathrm{CI}_{\text {shell }}$ of clams in all treatments 

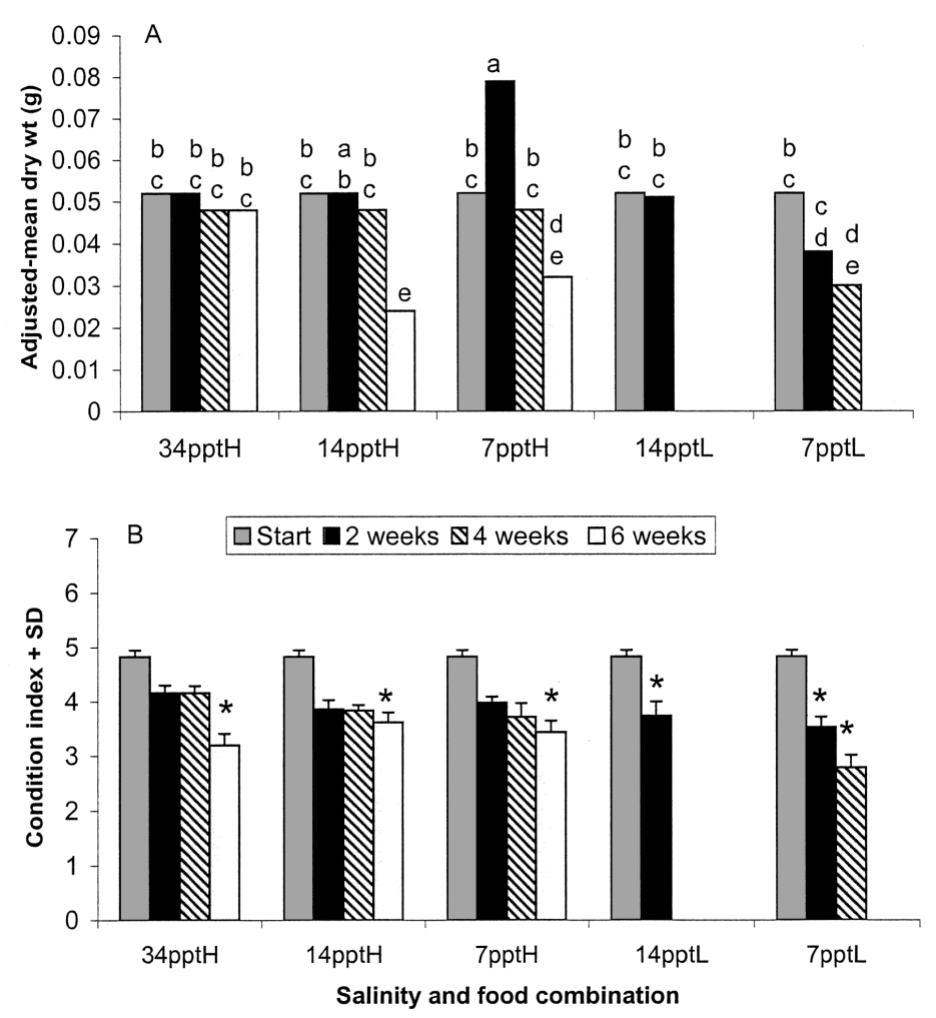

Fig. 3. Austrovenus stutchburyi. Effects of 14 and 7 $\%$ salinity on weight relationships of clams provided with high $(\mathrm{H})$ or low (L) phytoplankton diet at $15^{\circ} \mathrm{C}$ (Expt 2). Also included is the $34 \%$ high phytoplankton experiment used as a control for Expt 1. (A) Weight-adjusted mean (g), and (B) condition in$\operatorname{dex}(+\mathrm{SD})$. Means from regression lines that were similar share the same letter, $\mathrm{CI}_{\text {shell }}$ values with

* differ significantly from the starting value

larger individuals with an adjusted-mean dry tussue weight of more than $0.6 \mathrm{~g}$ (Fig. 4A). Both site and time affected the weight relationships of field clams (ANCOVA $F_{\text {all effects }}=$ 21.78) over the $6 \mathrm{wk}$ duration of Expt 1. The adjusted-mean dry tissue weight for Beachville clams was higher than Oxidation clams, which was higher than those from the other sites. Beachville clams maintained a high body weight throughout the 6 wk period, whereas, in clams from the other sites, the adjusted dry weight differed occasionally (Tukey's post-hoc test). Site also significantly affected clam $\mathrm{CI}_{\text {shell }}$ (Fig. 4B) (repeatedmeasures ANOVA $F=17.01$ ). There was no declined significantly after 6 wk (Fig. 3B) (ANOVA $F=5.72$ ).

Both the adjusted-mean dry tissue weight and the $\mathrm{CI}_{\text {shell }}$ were sensitive to the experimental regime, and these results confirm that Austrovenus stutchburyi is capable of surviving in low salinity conditions for considerable periods, providing that there are sufficient food resources available.

\section{Natural populations}

Austrovenus stutchbyri from all sites showed a linear relationship between log shell length and log dry tissue weight, and between log shell length and log dry shell weight (data not presented). At Beachville, which is the site closest to the estuary mouth, the population structure was dominated by

Fig. 4. Austrovenus stutchburyi. Weight relationships in 5 field populations over the 6 wk duration of Expt 1. (A) Adjusted-mean tissue dry weight (g). Means from regression lines that were similar share the same letter. (B) Condition index (+SD); those with * differ significantly from other values
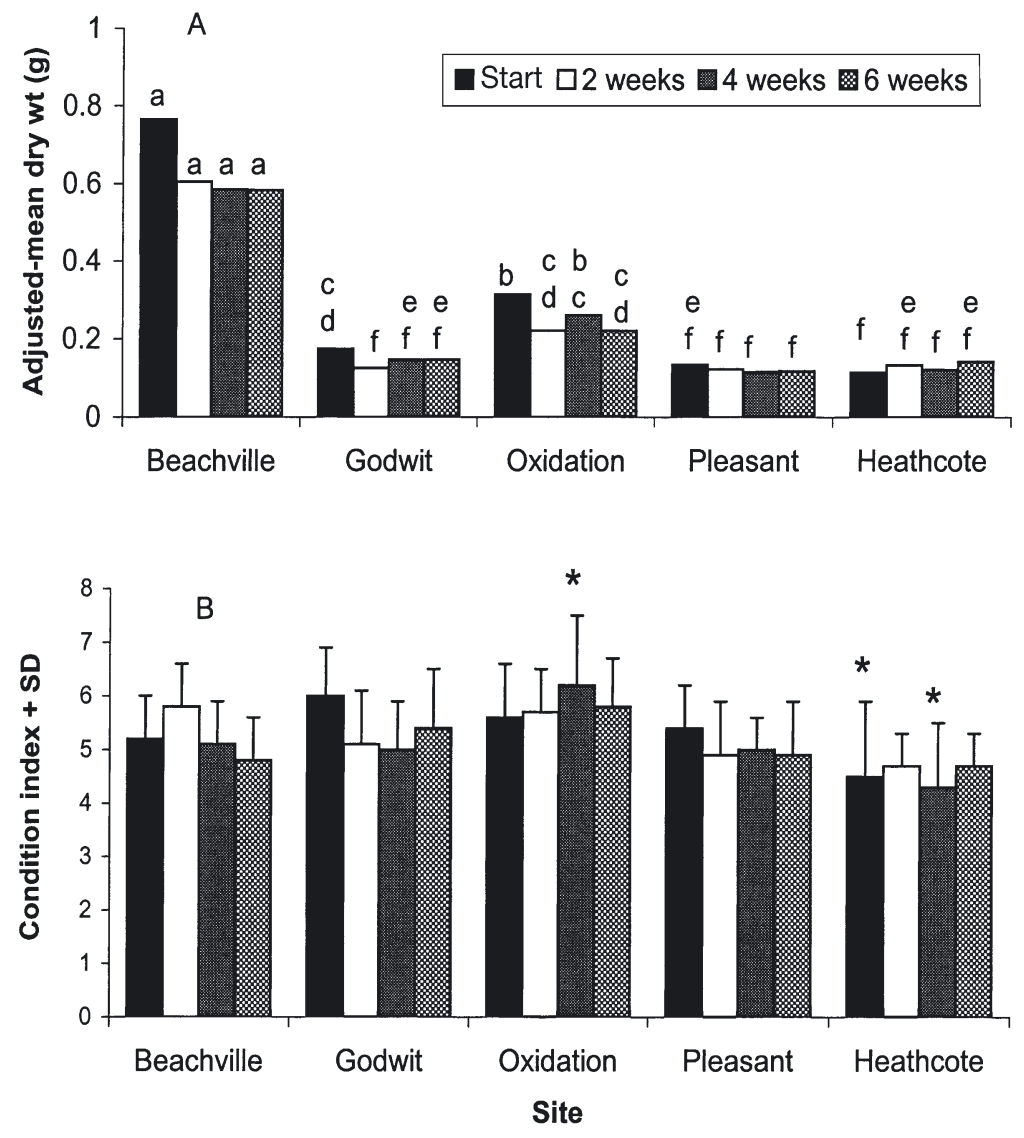
effect of sampling time $(F=1.06, \mathrm{p}=0.37)$, but there was a significant interaction between site and sampling time $(F=2.52)$. The $\mathrm{CI}_{\text {shell }}$ of Oxidation clams was higher than clams from other sites after Week 4 (Fig. 5B), and at this time the $\mathrm{CI}_{\text {shell }}$ of Heathcote clams was significantly lower than other samples (Tukey's post-hoc test). These results suggest that the $\mathrm{CI}_{\text {shell }}$ of field populations is not a predictable indicator of tissue weight increase over a $6 \mathrm{wk}$ period.

\section{Six-week transplant experiment}

The tissue-weight relationships of clams transplanted from Beachville to other sites varied amongst sites and with exposure time $\left(F_{\text {all effects }}=16.79, \mathrm{p}<0.001\right)$. Clams from the same collection used for Expt 1, caged back to their original site, maintained the same adjusted-mean weight over $6 \mathrm{wk}$ (Fig. 5A). Heathcote clams also maintained their initial tissue weight for $4 \mathrm{wk}$. In contrast, clams transplanted to Godwit and Pleasant Pt recorded significant weight loss following only 2 wk exposure at the new site. The $\mathrm{CI}_{\text {shell }}$ of the transplanted clams (Fig. 5B) was more variable over time than in clams from the established field populations. There was a significant effect of site and time on $\mathrm{CI}_{\text {shell }}$ of transplanted clams (ANOVA $F=19.22$ ), and for all sites, with the exception of Oxidation, the $\mathrm{CI}_{\text {shell }}$ was significantly reduced following $6 \mathrm{wk}$ exposure (Tukey's post-hoc test).

\section{Environmental variables}

Over the 6 wk duration of Expt 1 and the corresponding field transplant experiment, there were dif-

Table 2. Low-tide field measurements recorded on 4 sampling occasions during the $6 \mathrm{wk}$ of Expt 1 and field experiments

\begin{tabular}{|lcccc|}
\hline Site & $\begin{array}{c}\text { Seawater } \\
\text { temperature } \\
\left({ }^{\circ} \mathrm{C}\right)\end{array}$ & $\begin{array}{c}\text { Channel } \\
\text { salinity } \\
(\% \circ)\end{array}$ & $\begin{array}{c}\text { Channel } \\
\mathrm{chl} a \\
\left(\mu \mathrm{g} \mathrm{l}^{-1}\right)\end{array}$ & $\begin{array}{c}\text { Sediment } \\
\mathrm{chl} \mathrm{c} \\
\left(\mu \mathrm{g} \mathrm{l}^{-1}\right)\end{array}$ \\
\hline Beachville & $14.5-18$ & $22-30$ & $3.3-4.3$ & $11.3-16.5$ \\
Godwit & $14-15$ & $22-30$ & $4.3-12.2$ & $15.0-25.0$ \\
Oxidation & $13.8-15$ & $20-29$ & $7.0-8.1$ & $14.4-21.1$ \\
Pleasant Pt & $15-17$ & $8-15$ & $7.1-11.4$ & $19.1-25.0$ \\
Heathcote & $14-15$ & $8-12$ & $8.8-12.8$ & $4.6-34.4$ \\
\hline
\end{tabular}
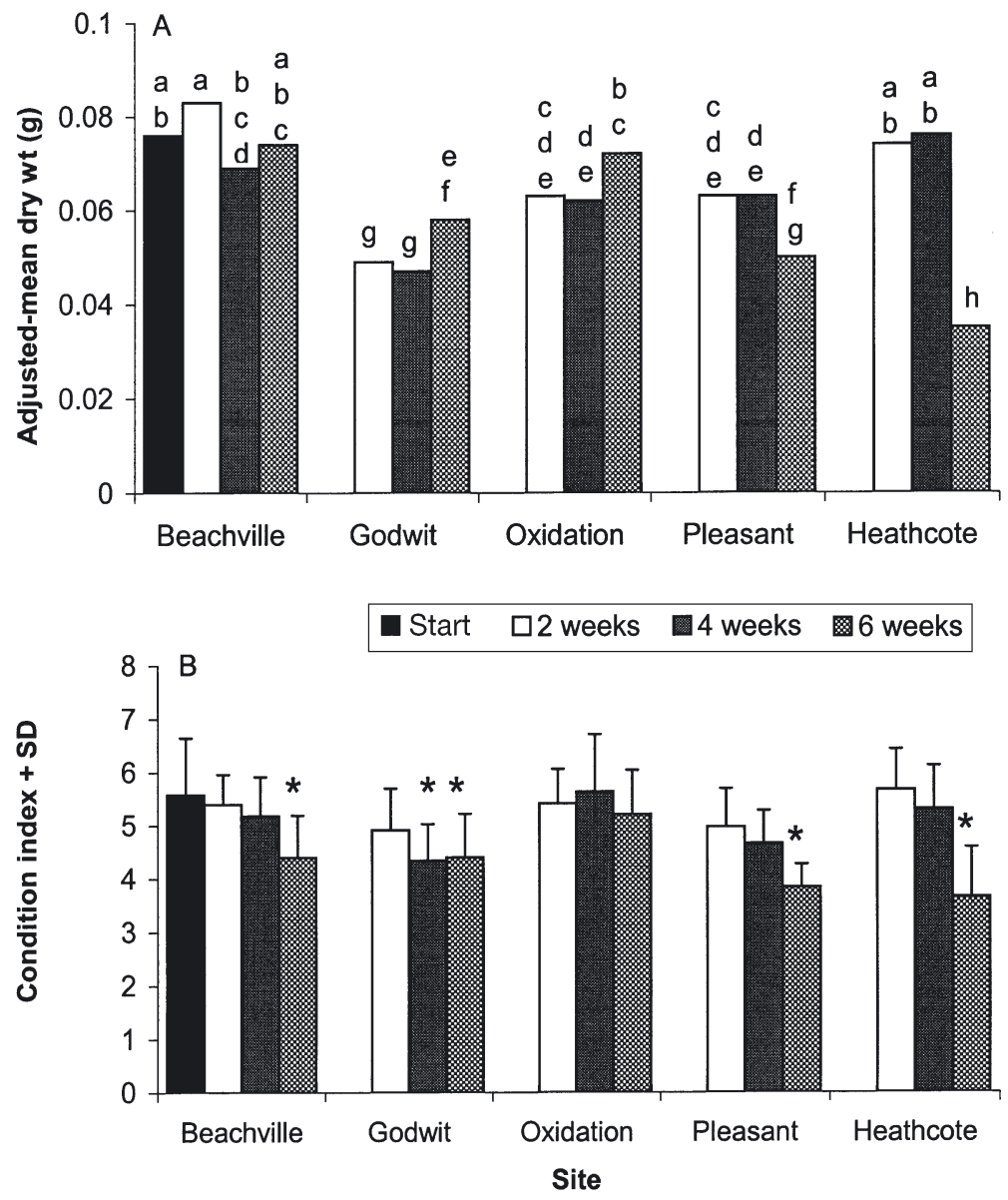

Fig. 5. Austrovenus stutchburyi. Weight relationships of clams collected from Beachville and transplanted to 5 sites within the estuary during Expt 1. (A) Adjusted-mean weight (g), and (B) condition index (+SD). Means from regression lines that were similar share the same letter; $\mathrm{CI}_{\text {shell }}$ values with * differ significantly from the starting value

ferences amongst the sites in salinity and chl a concentrations, both in seawater on the sediment surface and channel seawater (Table 2). Lowest salinities were recorded from Heathcote and Pleasant Pt, reflecting their further distance away from the estuary mouth. Surface sediment seawater chl a concentrations consistently exceeded channel chl a concentrations. Lowest concentrations occurred at Beachville, the site closest to the open sea. The low-tide seawater temperature range was similar for all sites.

Over the $6 \mathrm{~h}$ period surrounding high tide, seston availability and composition varied amongst the sites (Fig. 6). Chl a concentration varied with immersion time and location (2-way ANOVA $F_{\text {sites }}=4.0, F_{\text {time }}=$ 3.5), with highest variation at Godwit and Heathcote. At Beachville, the chl a concentrations were similar over the high-tide period, but they were consistently below concentrations recorded from Oxidation and 

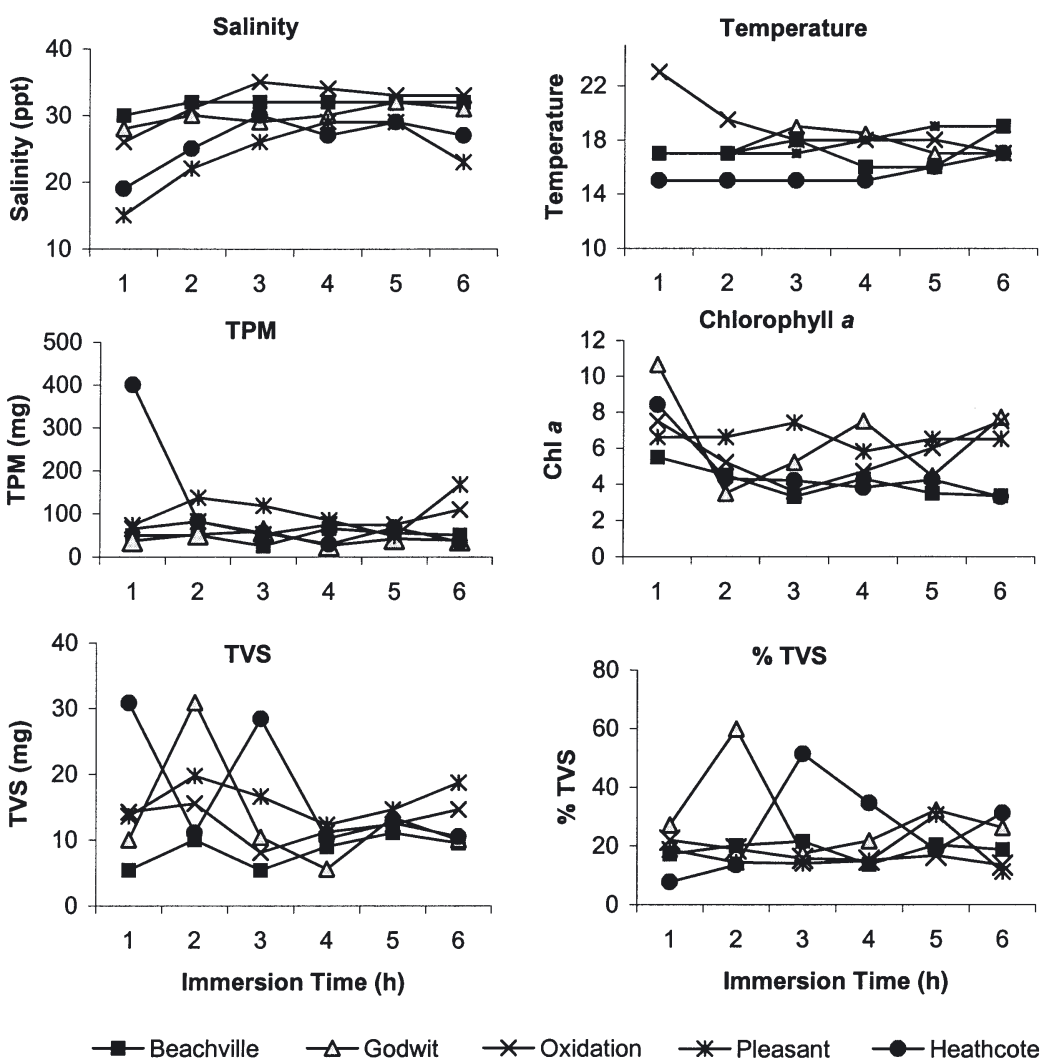

Fig. 6. Seawater and seston variability at the transplant sites over a $6 \mathrm{~h}$ period surrounding high tide during Week 4 of the field transplant experiment and laboratory Expt 1: mean salinity $(\%)$; seawater temperature $\left({ }^{\circ} \mathrm{C}\right)$; total particulate matter, TPM $\left(\mathrm{mg} \mathrm{l}^{-1}\right)$; chl a concentration $\left(\mu \mathrm{g} \mathrm{l} \mathrm{l}^{-1}\right)$; total volatile solids, TVS $\left(\mathrm{mg} \mathrm{l}^{-1}\right) ;$ and \% TVS

Pleasant Pt. Average values for total particulate matter (TPM) varied between 25 and $400 \mathrm{mg} \mathrm{l}^{-1}$, with no consistent pattern amongst sites or with time. Values were highest $3 \mathrm{~h}$ before or $3 \mathrm{~h}$ after high tide at the sites most
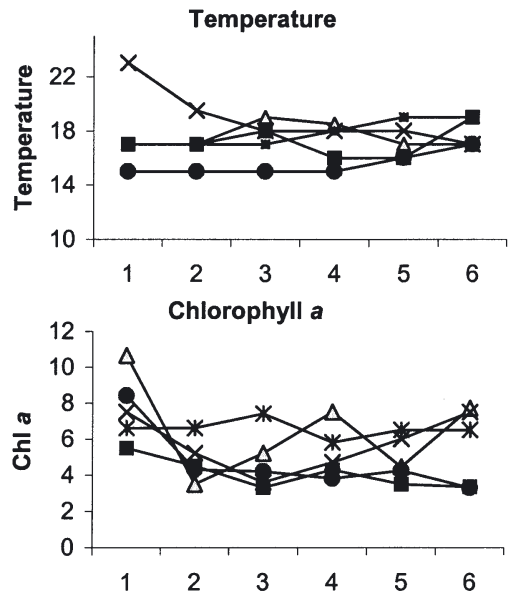
(15 to $20 \%$ ) at the sites influenced by river inputs and highest (>30\%) at sites closest to the estuary mouth. Over the 3 $\mathrm{h}$ surrounding the predicted time of high tide, the salinity exceeded $26 \%$ at all sites.

At high tide, there was significant variation in chl a concentrations of surface seawater and seawater at the sedimentwater interface (Fig. 7) (2-way ANOVA $F_{\text {sites }}=253.8 ; F_{\text {water mass }}=89.9 ; F_{\text {interaction }}=$ 168.9). Highest chl a concentrations occurred in the surface seawater at Oxidation, which receives waste-water discharge from setting ponds at high tide. At the 2 sites closest to the estuary mouth, the salinity was the same for the 2 water masses, but for the other sites the surface seawater was more saline. TVS also varied between the sites, but the values were similar for both water masses. In contrast with other results, the TPM values
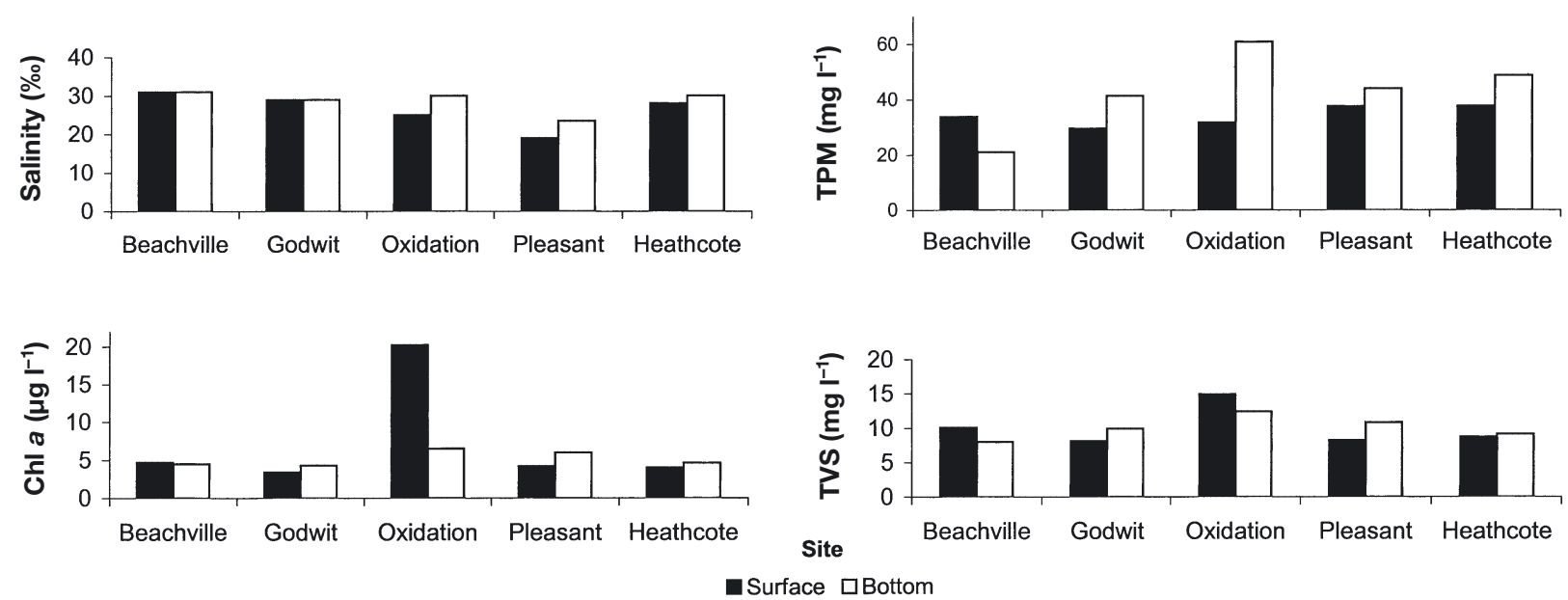

Fig. 7. Comparison of surface seawater variables with those from the sediment-surface interface at transplant sites during Week 4 of the field transplant experiment and laboratory Expt 1: salinity $(\%)$; total particulate matter, TPM $\left(\mathrm{mg} \mathrm{l}^{-1}\right)$; mean chl $a\left(\mu g \mathrm{l}^{-1}\right)$; and total volatile solids, TVS $\left(\mathrm{mg} \mathrm{l}^{-1}\right)$ 
Table 3. Low-tide field measurements, seawater temperature, salinity range and chl $a$, recorded during sampling over 6 mo (October to April 1997) of the field growth experiment

\begin{tabular}{|lccr|}
\hline Site & $\begin{array}{c}\text { Temperature } \\
\text { range }\left({ }^{\circ} \mathrm{C}\right)\end{array}$ & $\begin{array}{c}\text { Salinity } \\
\text { range }(\%)\end{array}$ & \multicolumn{1}{c|}{$\begin{array}{c}\text { Channel } \\
\text { chl a }\left(\mu g ~^{-1}\right)\end{array}$} \\
\hline Godwit & $14-22$ & $22-28$ & $9.3-15.4$ \\
Oxidation & $14-20$ & $20-26$ & $11.4-19.6$ \\
Pleasant Pt & $15-20$ & $8-21$ & $6.6-10.6$ \\
Heathcote & $14-20$ & $8-23$ & $8.3-13.8$ \\
\hline
\end{tabular}

were irregularly variable, with the highest value at the sediment-water interface over the Oxidation shellfish bed.

\section{Growth studies}

During the growth study (October to March), lowtide temperatures during sampling were similar at the 4 sites (Table 3 ), with highest temperatures recorded in February (late summer). Of the environmental factors measured, salinity variation was the feature that distinguished between sites. In clams from the natural populations, the adjusted-mean tissue dry weight varied amongst the sites (Fig. 8A) (ANCOVA $\left.F_{\text {all effects }}=8.26\right)$. Oxidation clams were significantly heavier than Heathcote clams for all sampling dates. At 3 of the sites there was little temporal variation in the adjusted-mean dry weight over 6 mo. However, at Pleasant Pt there was a significant weight increase from October to December.

The $\mathrm{CI}_{\text {shell }}$ of the established clam populations was variable amongst sites and at the different time intervals (Fig. 8B) (repeated-measures ANOVA $F_{\text {site }}=10.74$, $\mathrm{p}<0.001 ; F_{\text {time }}=12.27, \mathrm{p}<0.001, F_{\text {site }} \times$ time $=5.02, \mathrm{p}<0.001) . \mathrm{CI}_{\text {shell }}$ was similar over the 6 mo period in clams from Heathcote and Pleasant Pt. However, at Oxidation, $\mathrm{CI}_{\text {shell }}$ was significantly higher in December than in the other months and, at Godwit, it significantly declined from October to April (Tukey's post-hoc test). The $\mathrm{CI}_{\text {shell }}$ of field populations was negatively correlated with low tide chl a concentrations, and there was no correlation with either lowtide salinity or temperature (Table 4).

At the start of the experiment, clams from Beachville used in the growth experiment had a mean tissue $( \pm \mathrm{SD})$ dry weight of $0.043 \pm 0.026 \mathrm{~g}$. Highest mortality was recorded from Pleasant Pt (40\%) followed by Oxidation $(27 \%)$, Heathcote $(22 \%)$ and Godwit $(9 \%)$. The weight relationships amongst transplants differed over 6 mo (Fig. 9A) (ANCOVA $F_{\text {all effects }}=11.75, \mathrm{p}<0.001$ ) and divided into 7 groups with the same mean values (Tukey's post-hoc test). Clams from Oxidation recorded significant weight gain between February and April. At Godwit and Pleasant Pt, the transplanted clams maintained their body weights, contrasting with Heathcote clams which continued to loose weight from December to February. The $\mathrm{CI}_{\text {shell }}$ (Fig. 9B) varied significantly amongst sites (ANOVA $F=8.11$ ), with high values for clams transplanted to Oxidation. However, at each site, the $\mathrm{CI}_{\text {shell }}$ of transplanted clams was similar in December, February and April (Tukey's posthoc test).

All transplanted clams, regardless of site, had the same increase in shell length between October and December $($ mean $=0.74 \mathrm{~mm}, \mathrm{SD}=0.36)$. However, between December and April, shell growth was variable depending on site (Fig. 9C) (ANOVA $F=13.38$ ).
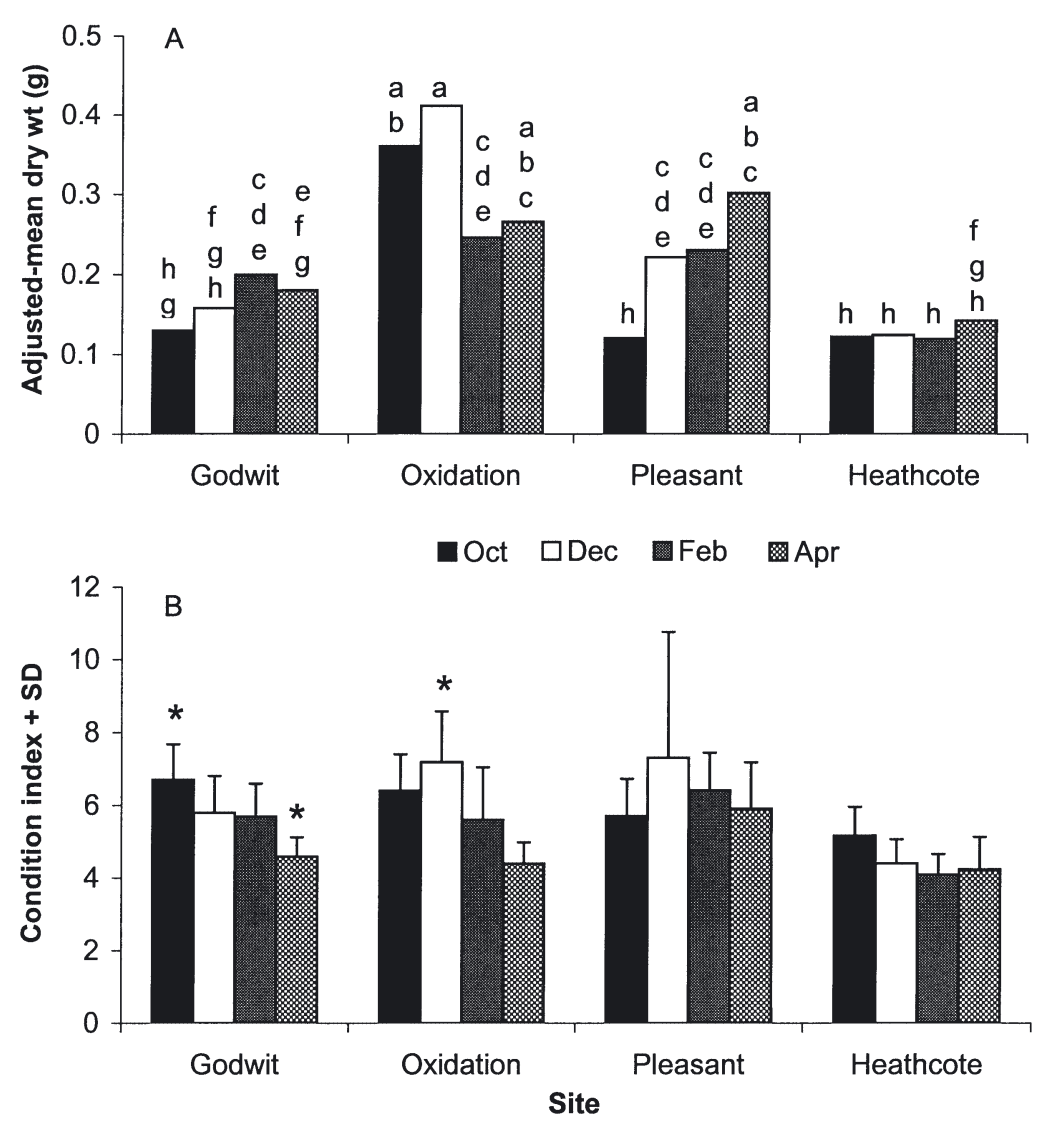

Fig. 8. Austrovenus stutchburyi. Weight relationships of field populations, October 1997 to April 1998. (A) Adjusted-mean dry tissue weight (g), and (B) condition index $(+\mathrm{SD})$. Means from regression lines that were similar share the same letter. At each site, $\mathrm{CI}_{\text {shell }}$ values with * differ significantly from other values 
Table 4. Correlation coefficients describing the relationships between length increment and condition index with low-tide environmental variables. LM, monthly length increment $(\mathrm{mm})$; L, total length increment $(\mathrm{mm})$; TCI, condition index of transplanted clams; TS, water temperature at the start of the growth period (October 1997); TE, temperature at the end of the period (April 1998); ChaS, chl a concentration at the start of the experiment; ChaE, chl a concentration at the end of the experiment; FCI, condition index of field population, SalS, salinity at start of the experiment; SalE, salinity at end of the experiment; Tv, seawater temperature variation; $\mathrm{S}$, average salinity; Cha, average chl a. The critical value for $\mathrm{p}<0.05$ is 0.53

\begin{tabular}{|c|c|c|c|c|c|c|c|c|c|c|c|c|c|}
\hline & LM & $\mathrm{L}$ & TCI & TS & $\mathrm{TE}$ & ChaS & ChaE & $\mathrm{FCI}$ & SalS & SalE & $\mathrm{Tv}$ & $\mathrm{S}$ & Cha \\
\hline LM & 1 & & & & & & & & & & & & \\
\hline L & 0.08 & 1 & & & & & & & & & & & \\
\hline TCI & 0.83 & 0.23 & 1 & & & & & & & & & & \\
\hline TS & -0.52 & 0.69 & -0.33 & 1 & & & & & & & & & \\
\hline TE & 0.07 & -0.17 & -0.05 & 0.38 & 1 & & & & & & & & \\
\hline ChaS & -0.07 & 0.49 & -0.16 & 0.56 & 0.64 & 1 & & & & & & & \\
\hline ChaE & -0.29 & 0.40 & -0.05 & 0.15 & 0.37 & -0.03 & 1 & & & & & & \\
\hline FCI & 0.56 & -0.30 & 0.36 & 0.40 & 0.28 & -0.41 & -0.58 & 1 & & & & & \\
\hline SalS & 0.24 & 0.54 & 0.16 & 0.36 & 0.14 & 0.22 & 0.12 & 0.08 & 1 & & & & \\
\hline SalE & 0.18 & 0.42 & 0.10 & 0.30 & 0.03 & 0.36 & 0.20 & -0.02 & 0.67 & 1 & & & \\
\hline $\mathrm{Tv}$ & 0.36 & -0.53 & 0.18 & -0.84 & 0.82 & -0.72 & 0.12 & 0.41 & -0.14 & -0.16 & 1 & & \\
\hline S & 0.11 & 0.52 & 0.06 & 0.44 & 0.03 & 0.27 & -0.13 & 0.06 & 0.93 & -0.81 & -0.26 & 1 & \\
\hline Cha & -0.28 & 0.61 & -0.17 & 0.48 & -0.17 & 0.65 & -0.73 & -0.72 & 0.21 & 0.39 & -0.40 & 0.26 & 1 \\
\hline
\end{tabular}
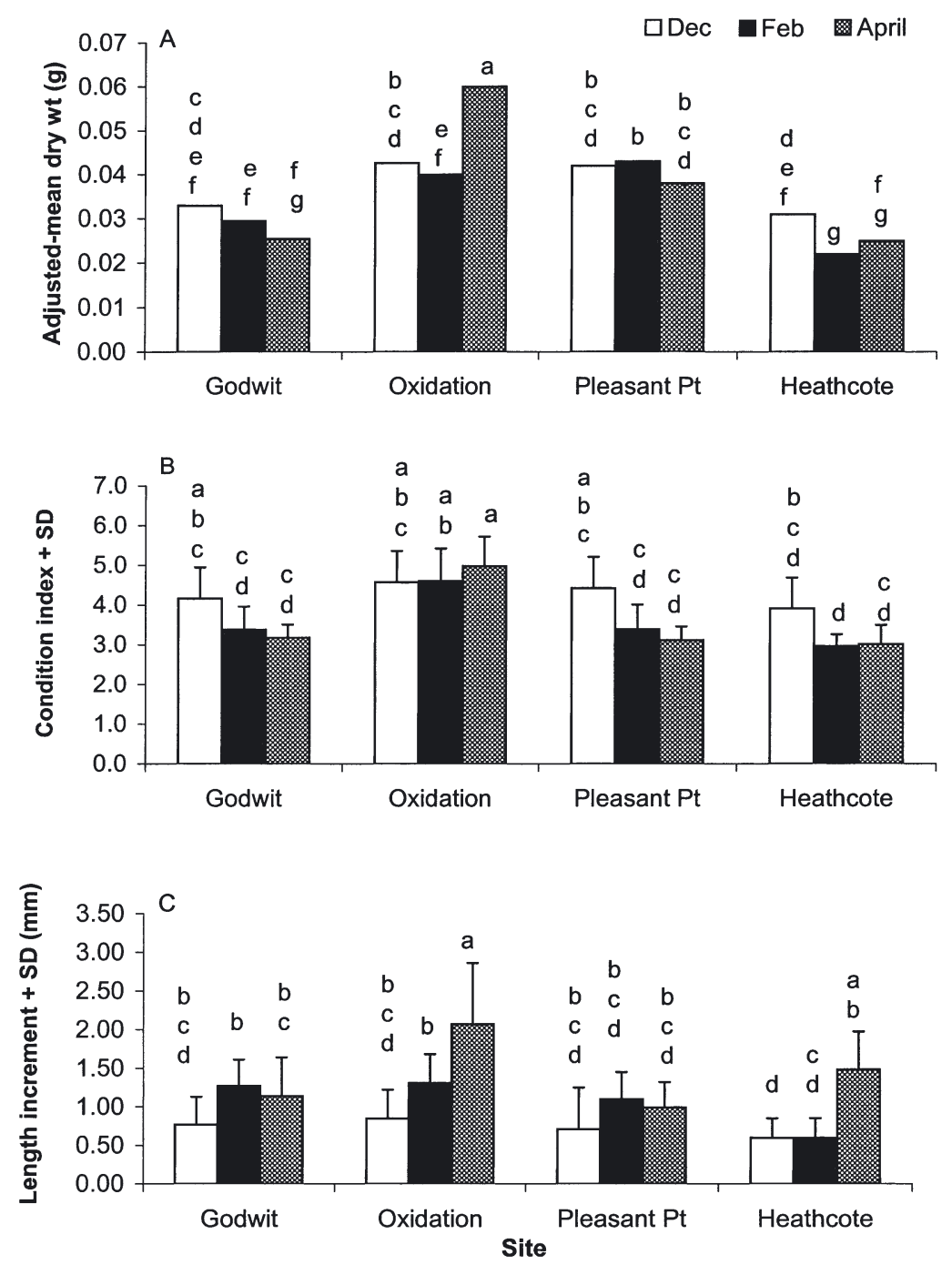

At Oxidation, shell growth was continuous from October to April. At Heathcote, clam shell-growth appeared inhibited between December and February, but by April the length increase was similar to the clams at Oxidation. In contrast with these results, there was no increase in shell length between December and April for Godwit and Pleasant Pt clams. Calculated over the 6 mo period, the growth rates were ca. $0.35 \mathrm{~mm} \mathrm{mo}^{-1}$ for Oxidation, $0.25 \mathrm{~mm} \mathrm{mo}^{-1}$ at Heathcote, $0.19 \mathrm{~mm} \mathrm{mo}^{-1}$ at Godwit and $0.17 \mathrm{~mm} \mathrm{mo}^{-1}$ at Pleasant Pt. For the 2 latter sites, more than $70 \%$ of the total growth occurred between October and December.

For all sites and time intervals combined, the total length increment of transplanted clams correlated positively with water temperature, low-tide salinity at the start of the growth period, and the average concentration for chl a (Table 4). The mean growth increment per month was positively correlated with the CI of the transplanted and established field populations. The $\mathrm{CI}_{\text {shell }}$ of

Fig. 9. Austrovenus stutchburyi. Field growth rates and weight relationships of clams transplanted from Beachville to 4 sites for 2, 4 and 6 mo between October 1997 and April 1998. (A) Adjusted-mean dry weight (g), (B) condition index $( \pm \mathrm{SD}) ;$ and $(\mathrm{C})$ average total length increment $(+\mathrm{SD}, \mathrm{mm})$. Means that were similar share the same letter 

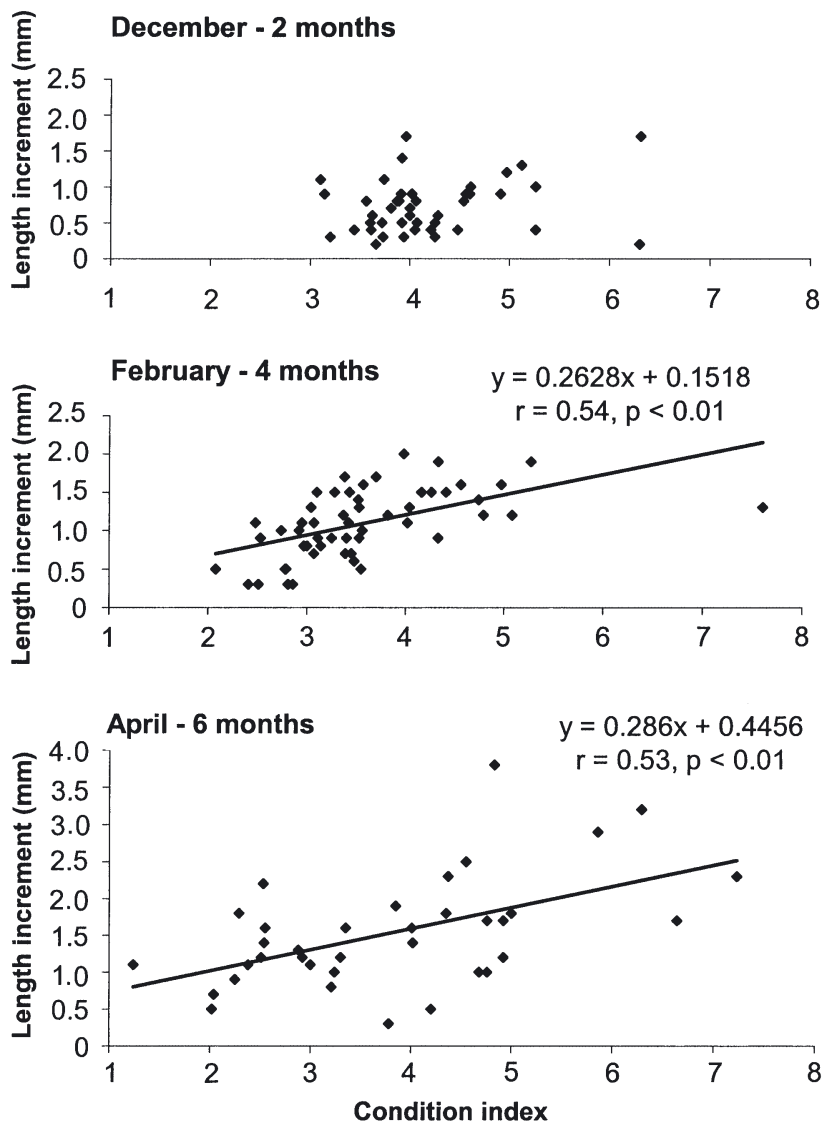

Fig. 10. Austrovenus stutchburyi. Relationship between length increment $(\mathrm{mm})$ and condition index $\left(\mathrm{CI}_{\text {shell }}\right)$ for clams transferred from Beachville in October 1997 and measured following 2, 4 and 6 mo exposure. Data from all sites were combined for each time interval. Also shown are the regression equations and the correlation coefficients. In December there was no significant relationship between the 2 variables

the field populations was correlated with average chl a concentration and water temperature, but not with low-tide salinity. Chl a concentration was positively correlated with seawater temperature.

The relationship between shell length increment and $\mathrm{CI}_{\text {shell }}$ was investigated by regression analysis by combining the data from all of the sites at the different time periods. There was no relationship at the end of the first $2 \mathrm{mo}$, but following 4 and $6 \mathrm{mo} \mathrm{CI}_{\text {shell }}$ was a reliable predictor of the length increment (Fig. 10).

\section{DISCUSSION}

In its estuarine habitat, the shallow-burrowing clam Austrovenus stutchburyi is subjected to fluctuations in salinity and food supply. The combined results from the present study show clearly that prolonged exposure to low salinity can stress the clams and reduce their condition, tissue weight and shell growth. The salinity response, however, depends upon both the quality and abundance of seston, in particular phytoplankton, determined by chl a concentrations.

\section{Laboratory study}

High phytoplankton availability did not result in marked tissue-weight gain of Austrovenus stutchburyi when exposed to seawater salinities of 34 and $20 \%$. Clams held in the laboratory at $15^{\circ} \mathrm{C}$ had similar dryweight relationships and $\mathrm{CI}_{\text {shell }}$ to both field transplants and natural populations. These results contrast with some other studies, where laboratory-held bivalves, provided with a unialgal food supply, were unable to maintain their condition compared with field populatins (Kiørboe et al. 1981, Bricelj et al. 1984, Lu \& Blake 1996). However, when clams were exposed to salinities $\leq 14 \%$ o there was mortality in the low phytoplankton treatment and the $\mathrm{CI}_{\text {shell }}$ was reduced. This change represents a loss in body tissue weight and most likely reflects increased energy demands of osmoregulation (Davenport 1979), altered metabolism (Navarro 1988) and/or disruption of the feeding mechanism. When exposed to extremes of environmental salinity, A. stutchburyi, like other marine and brackish-water molluscs, rapidly withdraws the exhalent siphon, closes the valves and reduces pumping rates, heart and ciliary beat (Davenport 1979, Gruffydd et al. 1984). Shell closure can delay exposure to unfavourable conditions, and the fluid inside the mantle cavity buffers internal tissues from the external environment (Shumway 1977).

When Austrovenus stutchburyi was maintained in low salinity conditions, a phytoplankton-only diet close to $5 \mu \mathrm{g} \mathrm{l}^{-1}$ provided insufficient nutrients for survival. This is a similar result to that for the brackish water mussel Choromytilus chorus, where the scope-forgrowth becomes negative at $15 \%$ o (Navarro 1988). New Zealand little-neck clams, like some other estuarine bivalves, Mya arenaria, Mercenaria mercenaria, Anadara granosa and Macoma balthica (Broom 1982, Arnold et al. 1991, Harvey \& Vincent 1991, Newell 1991), appear more salinity tolerant than mussels or scallops (Navarro \& Gonzalez 1998). Although immediate valve closure occurs in A. stutchburyi at salinities below $14 \%$ o (pers. obs.), the clams acclimate to lower salinities over a $2 \mathrm{wk}$ period. The remarkable ability of A. stutchburyi to maintain body condition at a low salinity with high phytoplankton availability suggests a flexible feeding mechanism, whereby clams are able to capture and assimilate food over a wide concentration range. 


\section{Field populations}

Many environmental and other factors affect the condition and growth of estuarine bivalves, and for this and other species, tidal level and density are amongst the most important (Walker \& Tenore 1984, Manzi et al. 1986, Dobbinson et al. 1989, Arnold et al. 1991, Harvey \& Vincent 1991, Marelli \& Arnold 1996). These factors were not considered in the present study because all the shellfish beds were at the same tidal elevation, population densities were similar, and there were few epibionts potentially competing with clams for food (Shriver et al. 2002). Seasonal trends in the weight relationships of Austrovenus stutchburyi were similar to those recorded for this species both within the study estuary and elsewhere in New Zealand (Larcombe 1971, Stephenson 1981, Marsden \& Pilkington 1995). Clams retain low tissue body-weight over winter (June and July), then weight increases rapidly as a result of somatic growth and gamete development in spring. Previous studies have suggested that spawning occurs in January or February, and in the present study there was weight loss, attributed to spawning in Oxidation clams between December and February. This site, with its intermediate salinity conditions and high phytoplankton and seston availability, appeared optimal for growth amongst the sites tested in field experiments. At Godwit (high salinity) and Pleasant Pt (low salinity) there was continuous weight gain but no loss that might be associated with spawning. At Heathcote, another low salinity site, there was no weight gain in field populations over the entire 6 mo period, and mature gonads were never observed. These results confirm spatial and temporal variations in growth, which could affect the reproductive activity of the clams within the estuary.

\section{Food resources}

Many cockles and clams that live in estuaries have variable food sources due to natural and anthropogenic inputs, and these tend to be variable over different time scales (Fegley et al. 1992, Eisma \& Li 1993, Hawkins et al. 1998). In addition, within shallow estuaries, like the Avon-Heathcote, wind and tide driven currents resuspend the bottom sediments (Zurburg et al. 1994, Guarini et al. 1998). If the sediments are mainly inorganic, then with increasing seston loads there will be a corresponding decrease in the organic component of the food resource. This can affect the feeding efficiencies and potentially the growth of some estuarine species (Urrutia et al. 1996). High seston loads were found in the Avon-Heathcote, reflecting differences in location and anthropogenic inputs. TPM was within the range
25 to $400 \mathrm{mg} \mathrm{l}^{-1}$, with highest values closest to the rivers and lowest values near the estuary mouth. The organic fraction was similar to other studies (Oviatt \& Nixon 1975), between 5 and $31 \mathrm{mg} \mathrm{l}^{-1}$, comprising between 8 and $60 \%$ of the total seston. At low tide, the organic fraction of the seston was most likely enhanced by benthic microalgal production, as in Grant et al. (1990) and Kang et al. (1999). Also, at 1 site (Oxidation), high-tide values were elevated following the release of treated effluent from settling ponds. Around high tide, the chl a concentration at the sediment-water interface of the shellfish beds was variable between sites, and generally low, between 5 and $8 \mu \mathrm{g} \mathrm{l}^{-1}$. These concentrations are the same as the seawater flowing into the estuary from Pegasus Bay (Marsden 1999). Previous studies have reported much higher chl a concentrations in estuaries, ranging between 15 and $27 \mathrm{\mu g} \mathrm{l}^{-1}$ in summer, and values are $10 \mathrm{~g} \mathrm{l}^{-1}$ in autumn (Kaufman et al. 1983). While the high-tide $\mathrm{chl} a$ concentrations recorded in the present study would not provide sufficient energy for positive scope-for-growth in some bivalves, they would support maximal growth in the mussel Mytilus edulis (Clausen \& Riisgard 1996). However, in the bay scallop (Shriver et al. 2002) and the New Zealand little-neck clam, food concentrations of less than $5 \mu \mathrm{g} \mathrm{l}^{-1}$ appear to limit growth. In considering the food quality of the seston available to the clams, it must be stressed that there are inaccuracies in estimating food availability. The chl a measurements recorded during this study were measured directly over the shellfish beds, and seston availability could have been lowered due to the feeding activity of the bivalves (Muschenheim \& Newell 1992).

\section{Field transplants}

Although a number of field studies have evaluated the effects of tidal currents and seston availability on the growth of bivalves using field transplants (Wilson 1987, Shriver et al. 2002), few have investigated the effects of these variables on infaunal species. In the hard clam Mercenaria mercenaria, which is taxonomically close to Austrovenus stutchburyi (Jones 1979), growth rate differed by approximately $11 \%$ between sites. (Grizzle \& Morin 1989). These differences correlated with seton fluxes with only a $5.7 \%$ difference due to sediment type. $M$. mercenaria growth depended on density (Marelli \& Arnold 1996), and growth rates were higher in sand than mud, where it is thought that silt and clay may interfere with the feeding mechanism. In the present study, there were dramatic differences in growth rate between sites, with a $50 \%$ difference in the length increment between individuals from the fastest and slowest growing areas. The slow 
growing individuals were from sites dominated by low salinities, and these sites also had a higher proportion of silt and clay in the sediments.

Dobbinson et al. (1989) transplanted small (17 mm shell length) Austrovenus stutchburyi from high- and mid-tide to the low-tide region of a sheltered, almost fully saline, sand flat. Clam shell-length increased rapidly from September to March, as in the present study, then slowed in autumn. However, the shell growth rates were from 2 to 4 times faster than estimates from the Avon-Heathcote. Slow growth rates have been recorded previously for cockles, for example Cerastoderma edule in a eutrophicated bay in the Kattegat (Loo \& Rosenberg 1989), characterised by mass mortalities of bivalves and dense macroalgal mats. Similar mats, comprised of Ulva sp. and Gracilaria sp., also occur in the Avon-Heathcote during spring and summer, and these may have contributed to the low growth rates recorded here both for tissue weight and shell length.

To try to understand the combined effects of salinity and food resources on bivalve growth, Ceccherelli \& Barboni (1983) measured the growth of Mytilus galloprovincialis at 2 sites in Italy where the salinity range was 11 to $29 \%$. Chl a fluctuated between $18.7 \pm 17.2$ at Site 1 and $8.5 \pm 12.3 \mathrm{mg} \mathrm{m}^{-3}$ at the other site, where there was more suspended inorganic detritus and silt carried by tidal floods. In that study, tissue weight increased with food availability and reduced with increasing quantities of silt.

In the present study, clams were relocated from an almost fully marine site to less saline parts of the estuary. There was little initial mortality, suggesting that these clams have a fairly wide tolerance for salinity, regardless of their prior history. Shell increase of the transplants was positively correlated with temperature, low-tide salinity and chl a concentrations. The New Zealand little-neck clam, therefore, has the same growth response to increased phytoplankton and temperature as many mussel species, whereby growth increases as a function of food concentration (Bayne \& Worrall 1980, Bayne \& Newell 1983, Hickman et al. 1991, Perez Camacho et al. 1995). These results, however, appear to contrast with a recent study on the scallop Argopecten irradians from estuarine areas (Shriver et al. 2002). In that study, the high growth rate was independent of the ambient phytoplankton, which was considered to be in excess of the consumption ability.

It might be predicted that in estuaries like the AvonHeathcote, which receive nutrient inputs from a number of different sources, there would always be an abundant food supply, sufficient to maximise assimilation and resulting in high growth rates. However, seston measurements suggest that the optimal food supply (either quantity or quality) may not always be available, and this could reduce the growth rate and increase mortality. In the scallop Austrovenus irradians (Shriver et al. 2002), there was reduced growth and decreased survival at low salinities, which also occurred where food availability was reduced in the presence of competitors. Both the present study and that by Shriver et al. (2002) therefore highlight the importance of salinity and food availability on the growth rates of bivalves. In addition, the present study confirms that the salinity effects become more pronounced with low phytoplankton availability.

\section{Clam condition index and growth}

Numerous studies suggest that the $\mathrm{CI}_{\text {shell }}$ index of Crosby \& Gale (1990) is a reliable indicator of stress in bivalves. In mussels, reduced food levels, represented by low chl a concentrations, result in significant declines in condition (Hickman et al. 1991, Perez Camacho et al. 1995). In Austrovenus stutchburyi the $\mathrm{CI}_{\text {shell }}$ was not as rapid a stress indicator as the dryweight estimates. However, it detected differences in clam health amongst field populations, transplants and laboratory experiments. While in the field studies it was not possible to establish whether the stress was primarily due to low salinity, food availability, or some other aspect of the environment, the laboratory studies clearly indicated that low phytoplankton concentrations were more stressful to clams than reduced salinity. The present study also confirmed that the $\mathrm{CI}_{\text {shell }}$ of the little-neck clam reflected the growth potential. This supports the research findings of Shriver et al. (2002) on bay scallops, which was one of the first studies to directly relate shell growth-increment to bivalve condition. In A. stutchburyi, the lack of a direct relationship within the first 2 mo of transplant suggests that the initial growth rate was dependent on metabolic reserves available on transfer.

There is a complex relationship between the quantity of inorganic suspended sediment in the food resources and growth in bivalves, with sediments having either a negative or a positive effect. Particulate inorganic matter (PIM) and silt improve algal absorption in species such as Mercenaria mercenaria (Bricelj \& Malouf 1984). Some cockles, like Cerastoderma Edule, are able to maintain high feeding efficiencies when exposed to fluctuations of total particulate matter (TPM) within the range 15 to $95 \mathrm{mg} \mathrm{l}^{-1}$ during tidal inundation (Urrutia et al. 1996). Clams regulate clearance rates and pseudofaeces production in high seston by preferentially ingesting algal components of the diet over a wide concentration range (Navarro \& Widdows 1997). A similar ability has been demonstrated in a number of temperate and tropical bivalves (Hawkins 
et al. 1998). If, as seems likely in Austrovenus stutchburyi, the absorption efficiency is increased due to the presence of silt, then this clam could compensate for low concentrations of chl a in the seston. Similarly, if silt had been added to the diet in the laboratory study, the clams may have been less sensitive to the effects of reduced salinities.

When evaluating the effects of environment on the growth of bivalves, it is important to consider their specific feeding mechanisms and behaviour. Austrovenus stutchburyi is unusual amongst bivalves because it has an endogenous tidal rhythm of shell gaping and siphon extension centred over $4 \mathrm{~h}$ at high tide (Beentjes \& Williams 1986). At this time, the phytoplankton concentrations may be relatively low but the seston tends to be rich in organic matter. At low tide, although there is an abundant microphytobenthic food resource, inorganic material from rivers would tend to reduce the food value. By feeding at high tide, these clams avoid exposure to low-salinity seawater that can result in shell closure and delay feeding. In low-salinity habitats, shell closure most likely reduces feeding time and therefore food uptake. Unless there is a high availability of phytoplankton, there could be insufficient food resources to maintain clam condition and promote tissue and shell growth.

Acknowledgements. I wish to thank Bryn and Celyn Fenwick for their help in the field and the laboratory. This work was financed by a research grant from the Zoology Department, University of Canterbury. I would also like to thank an anonymous reviewer for providing constructive comments.

\section{LITERATURE CITED}

Arnold WS, Marelli DC, Bert TM, Jones DS, Quitmyer (1991) Habitat specific growth of hard clams Mercenaria mercenaria (L.) from the Indian River, Florida. J Exp Mar Biol Ecol 147:245-265

Bayne BL, Newell RC (1983) Physiological energetics of marine molluscs. In: Wilbur KM (ed) The Mollusca. Academic Press, New York, p 407-515

Bayne BL, Worrall CM (1980) Growth and production of mussels Mytilus edulis from two populations. Mar Ecol Prog Ser 3:317-328

Beentjes MP, Williams BG (1986) Endogenous circatidal rhythmicity in the New Zealand cockle Chione stutchburyi (Bivalvia, Veneridae). Mar Behav Physiol 12:71-180

Blackwell RG (1984) Aspects of the population dynamics of Chione stutchburyi in Ohewa Harbour, Bay of Plenty, New Zealand. PhD thesis, University of Auckland

Bricelj VM, Malouf RE (1984) Influence of algal and suspended sediment concentrations on the feeding physiology of the hard clam Mercenaria mercenaria. Mar Biol 84: 155-165

Bricelj VM, Malouf RE, de Quillfeldt C (1984) Growth of juvenile Mercenaria mercenaria and the effect of resuspended bottom sediments. Mar Biol 84:167-173

Broom MJ (1982) Analysis of the growth of Anadara granosa
(Bivalvia: Arcidae) in naturally, artificially seeded and experimental populations. Mar Ecol Prog Ser 9:69-79

Ceccherelli VU, Barboni A (1983) Growth, survival and yield of Mytilus galloprovincialis Lamk. on fixed suspended culture in a bay of the Po River Deta. Aquaculture 34:101-114

Clausen I, Riisgard HU (1996) Growth, filtration and respiration in the mussel Mytilus edulis: no evidence for physiological regulation of the filter-pump to nutritional needs. Mar Ecol Prog Ser 141:37-45

Crosby MP, Gale LD (1990) A review of bivalve condition index methodologies with a suggested standard method. J Shellfish Res 9:233-239

Davenport J (1979) Is Mytilus edulis a short term osmoregulator? Comp Biochem Physiol A 64:91-95

Dobbinson SJ, Barker MF, Jillett JB (1989) Experimental shore level transplantation of the New Zealand cockle Chione stutchburyi. J Shellfish Res 9:197-212

Eisma D, Li A (1993) Changes in suspended-matter floc size during the tidal cycle in the Dollard Estuary. Neth J Sea Res 31:107-117

Fegley SR, MacDonald BA, Jacobsen TR (1992) Short term variation in the quantity and quality of seston available to benthic suspension feeders. Estuar Coast Shelf Sci 34: 393-412

Gardner PA, Thompson RJ (2001) The effects of coastal and estuarine conditions on the physiology and survivorship of the mussels Mytilus edulis, M. trossulus and their hybrids. J Exp Mar Biol Ecol 265:119-140

Grant J (1996) The relationship between bioenergetics and the environment to the field growth of cultured bivalves. J Exp Mar Biol Ecol 200:239-256

Grant J, Thorpe B (1991) Effects of suspended sediment on growth, respiration and excretion of the soft-shell clam (Mya arenaria). Can J Fish Aquat Sci 48:1285-1292

Grant J, Enright CT, Griswold A (1990) Resuspension and growth of Ostrea edulis, a field experiment. Mar Biol 104: 51-59

Grizzle RE, Morin PJ (1989) Effect of tidal currents, seston, and bottom sediments on growth of Mercenaria mercenaria: results of a field experiment. Mar Biol 102:85-93

Gruffydd LLD, Huxley R, Crisp DJ (1984) The reduction in growth of Mytilus edulis in fluctuating salinity regimes measured using laser diffraction patterns and the exaggeration of this effect by using tap water as a diluting medium. J Mar Biol Assoc UK 64:401-409

Guarini JM, Blanchard GF, Bacher C, Gros P and 6 others (1998) Dynamics of spatial patterns of microphytobenthic biomass: inferences from a geostatistical analysis of two comprehensive surveys in Marennes-Oleron Bay (France). Mar Ecol Prog Ser 166:131-141

Harvey M, Vincent B (1990) Density, size distribution, energy allocation and seasonal variations in shell and soft tissue growth at two tidal levels of a Macoma balthica (L.) population. J Exp Mar Biol Ecol 142:151-168

Harvey M, Vincent B (1991) Spatial variability of lengthspecific production in shell, somatic tissue and sexual products of Macoma balthica in the Lower St. Lawrence Estuary. Small and meso scale variability. Mar Ecol Prog Ser 75:55-66

Hawkins AJS, Smith RFM, Tan SH, Yasin B (1998) Suspensionfeeding behaviour in tropical bivalve molluscs: Perna viridis, Crassostrea belcheri, C. iradelei, Saccostrea cucculata and Pinctada margarifera. Mar Ecol Prog Ser 166:173-185

Hickman RW, Waite RP, Illingworth J, Meredyth-Young JL, Payne G (1991) The relationship between farmed mussels, Perna canaliculus, and available food in PelorusKenepuru Sound, New Zealand. Aqauaculture 99:49-68 
Iglesias JIP, Navarro E, Alvarez Jorna, Armentia I (1992) Feeding, particle selection and absorption in cockles Cerastoderma edule (L.) exposed to variable conditions of food concentration and quality. J Exp Mar Biol Ecol 162:177-198

Iglesias JIP, Perez Camacho A, Navarro E, Labarta U, Beiras R, Hawkins AJS, Widdows J (1996) Microgeographic variability in feeding, absorption, and condition of mussels (Mytilus galloprovincialis Lmk.): a transplant experiment. J Shellfish Res 15:673-680

Jones CC (1979) Anatomy of Chione cancellata and some other Chionines (Bivalvia:Veneridae). Malacalogia 19: 157-199

Kang CK, Sauriau P-G, Richard P, Blanchard GF (1999) Food sources of the infaunal suspension-feeding bivalve Cerastoderma edule in a muddy sandflat of Marennes-Oleron Bay, as determined by analyses of carbon and nitrogen stable isotopes. Mar Ecol Prog Ser 187:147-158

Kaufman ZG, Lively JS, Carpenter EJ (1983) Uptake of nitrogenous nutrients by phytoplankton in a barrier island estuary: Great South Bay, New York. Estuar Coast Shelf Sci 17:483-495

Kautsky N (1982) Growth and size structure in Baltic Mytilus edulis populations. Mar Biol 68:117-133

Kiørboe T, Møhlenberg F, Nøhr O (1981) Effect of suspended bottom material on growth and energetics in Mytilus edulis. Mar Biol 61:283-288

Larcombe MF (1971) The ecology, population dynamics and energetics of some soft shore molluscs. PhD thesis, University of Auckland

Loo LV, Rosenberg R (1989) Bivalve suspension-feeding dynamics and benthic-pelagic coupling in an eutrophicated marine bay. J Exp Mar Biol Ecol 130:253-276

Lu YT, Blake NJ (1996) Optimum concentrations of Isochrysis galbana for growth of larval and juvenile bay scallops, Argopecten irradians concentricus (Say). J Shellfish Res 3: 635-643

Manzi JJ, Hadley NH, Maddox MB (1986) Seed clam, Mercenaria merenaria, culture in an experimental-scale upflow nursery system. Aquaculture 54:301-311

Marelli DC, Arnold WS (1996) Growth and mortality of transplanted juvenile hard clams, Mercenaria mercenaria, in the Indian River Lagoon, Florida. J Shellfish Res 15: $719-713$

Marsden ID (1999) Reproductive cycles of the surf beach clam Paphies donacina (Spengler,1791) from New Zealand. J Shellfish Res 18:539-546

Marsden ID, Pilkington RM (1995) Spatial and temporal variations in the condition of Austrovenus stutchburyi Findlay, 1927 (Bivalvia:Veneridae) from the Avon-Heathcote Estuary, Christchurch. NZ Nat Sci 22:57-67

Muschenheim DK, Newell CR (1992) Utilisation of seston flux over a mussel bed. Mar Ecol Prog Ser 85:131-136

Navarro JM (1988) The effects of salinity on the physiological ecology of Choromytilus chorus (Molina, 1792) (Bivalvia:

Editorial responsibility: Kenneth Tenore (Contributing Editor), Solomons, Maryland, USA
Mytilidae). J Exp Mar Biol Ecol 122:19-33

Navarro JM, Gonzales CM (1998) Physiological responses of the Chilean scallop Argopecten purpuratus to decreasing salinities. Aquaculture 167:315-327

Navarro JM, Widdows J (1997) Feeding physiology of Cerastoderma edule in response to a wide range of seston concentrations. Mar Ecol Prog Ser 152:175-186

Newell CR (1991) The soft shell clam Mya arenaria (Linnaeus) in North America. In: Menzel W (ed) Estuarine and marine mollusk culture. CRC Press, Boca Raton, FL, p 1-10

Oviatt CA, Nixon SW (1975) Sediment resuspension and deposition in Narragansett Bay. Estuar Coast Mar Sci 3: 201-217

Perez Camacho A, Labarta U, Beiras R (1995) growth of mussels (Mytilus edulis galloprovincialis) on cultivated rafts: influence of seed source, cultivation site and phytoplankton availability. Aquaculture 138:349-362

Rainer JS, Mann R (1992) A comparison of methods for calculating condition index in eastern oysters, Crassostrea virginica (Gmelin, 1791). J Shellfish Res 11:55-58

Shriver AC, Carmichael RH, Valiela, I (2002) Growth, condition, reproductive potential, and mortilaity of bay scallops, Argopecten irradians, in response to eutrophic-driven changes in food resources. J Exp Mar Biol Ecol 279:21-40

Shumway SE (1977) The effect of fluctuating salinity on the tissue water content of eight species of bivalve mollusc. J Comp Physiol 116:269-285

Shumway SE (1982) Oxygen consumption in oysters: an overview. Mar Biol Lett 3:1-23

Shumway SE, Newell RC (1984) Energy resource allocation in Mulinia lateralis (Say) an opportunistic bivalve from shallow water sediments. Ophelia 23:101-118

Stephenson RL (1981) Aspects of the energetics of the cockle Chione stutchburyi in the Avon-Heathcote Estuary, Christchurch, New Zealand. PhD thesis, University of Canterbury

Thompson JK, Nichols FH (1988) Food availability controls seasonal cycle of growth in Macoma balthica (L.) in San Fransisco Bay, California. J Exp Mar Biol Ecol 116:43-61

Urrutia MB, Iglesias JIP, Navarro E, Prou J (1996) Feeding and absorption in Cerastoderma edule under environmental conditions in the Bay of Marennes-Oleron (Western France). J Mar Biol Assoc UK 76:431-450

Walker RL, Tenore KR (1984) The distribution and production of the hard clam, Mercenaria mercenaria, in Warsaw Sound, Georgia. Estuaries 7:19-27

Wilson JH (1987) Environmental parameters controlling growth of Ostrea edulis L. and Pecten maximus L. in suspended culture. Aquaculture 64:119-131

Zar JH (1999) Biostatistical analysis. Prentice Hall, Upper Saddle River, NJ

Zurburg W, Small AAD, Heral M, Danker N (1994) Seston dynamics and bivalve feeding in the Bay of MarennesOleron (France). Neth J Aquat Ecol 28:459-466

Submitted: January 14, 2003; Accepted: September 3, 2003 Proofs received from author(s): January 9, 2004 